GAMBARAN KARAKTERISTIK PENDERITA NEUROPATI PERIFER DIABETIK
NURSCOPE Jurnal Keperawatan dan

Pemikiran IImiah

Suyanto (2017). Gambaran karakteristik

penderita neuropati perifer diabetik. Nurscope. Jurnal Keperawatan dan Pemikiran Ilmiah. 3 (1). 1-6

\author{
Suyanto ${ }^{1}$ \\ Fakultas IImu Keperawatan, Universitas Islam Sultan Agung Semarang
}

\title{
ABSTRAK
}

Pendahuluan: Penderita Diabetes Mellitus (DM) dalam jangka waktu yang lama bisa mengalami neuropati perifer diabetik. Penelitian ini bertujuan mengetahui gambaran karakteristik penderita neuropati perifer diabetik. Metodologi: deskripif analitik dengan desain cross sectional, 35 orang (sampel) yang didapat dengan tehnik purposive sampling. Sampel penelitian yaitu pasien neuropati perifer diabetik dengan skor sensasi kaki maksimal 8. Hasil: Hasil uji distribusi frekuensi menunjukkan ratarata usia responden $49.5 \pm 6,7$, jenis kelamin perempuan $(68,4 \%)$, lama menderita diabetes mellitus $4,6 \pm 2$, terapi farmakologi dominan Obat Hipoglikemik Oral $(\mathrm{OHO})(84,1 \%)$ dan rata-rata nilai Ankle Brachial Index (ABI) $0.85 \pm 0.05$, skor rata-rata sensasi kaki $8 \pm 0$,8. Diskusi: karakteristik penderita yang mengalami neuropati perifer diabetik sangat beragam, perlu kiranya dilihat korelasi antar karakteristik dengan kejadian neuropati perifer diabetik

Kata kunci : Diabetes Melitus, Neuropati Perifer Diabetik, Sensasi Kaki

\section{CHARACERISTICS OF DIABETIC PERIPHERAL NEUROPATIC}

\section{ABSTRACT}

Introduction: Diabetes Mellitus (DM) for a long time may experience diabetic peripheral neuropathy (DPN). This study aims to determine the characteristics of diabetic peripheral neuropathy. Methodology: descriptive analytic design with cross sectional design used with 35 samples obtained with purposive sampling technique. The sample of the research was diabetic peripheral neuropathy patients with maximum leg sensitivity score 8 . Results: The frequency distribution test results showed the average age of respondents $49.5 \pm 6.7$, female gender (68.4\%), diabetes mellitus $4.6 \pm 2$, dominant pharmacological treatment of Oral Hypoglycemic Drugs $(\mathrm{OHO})(84.1 \%)$ and average $A B I$ values $0.85 \pm 0.05$, mean foot sensation score of $8 \pm 0.8$. Discussion: the characteristics of patients with diabetic peripheral neuropathy are very diverse, it is necessary to see the correlation between characteristics with the incidence of diabetic peripheral neuropathy.

Keywords: Diabetic Mellitus, Diabetic Peripheral Neuropathy, Legs Sensitivity

Corresponding Author:

Suyanto $^{1}$, Fakultas IImu Keperawatan Universitas Islam Sultan Agung, Jalan Raya Kaligawe Km 4, Semarang, Jawa Tengah, Indonesia, Kode pos 50112; e-mail suyanto@unissula.ac.id

\section{PENDAHULUAN}

Beberapa penyakit kronik semakin meningkat kejadiannya di seluruh dunia. Salah satuny yang ada di Indonesia adalah Diabetes melitus (DM). Komplikasi DM terbagi menjadi 2, yaitu komplikasi makrovaskular dan mikrovaskular (Black \& Hawk, 2009). Komplikasi mikrovaskular menyerang pada 
pembuluh-pembuluh darah kecil, diantaranya terjadi di mata, ginjal, dan saraf perifer yang dapat menyebabkan terjadinya neuropati perifer diabetik (DPN) (Ignatavicius \& Workman, 2010).

Insidensi neuropati perifer diabetik terjadi antara $60 \%$ sampai $70 \%$ pada pasien DM tipe I dan tipe II. Neuropati perifer diabetik secara umum akan menimbulkan gejala khas diantaranya adalah parastesia distal, kaki menjadi terasa dingin, dan adanya nyeri yang khas yang dideskripsikan seperti nyeri terbakar atau bahkan seperti tertusuk-tusuk. Adapun tanda dan gejala lainnya meliputi berkurangnya sensasi sensori seperti penurunan stimulus sentuhan atau getaran, nyeri, dan suhu (Lemone \& Burke, 2008).

Dampak dari adanya neuropati perifer diabetik yang salah satunya adalah penurunan sensasi sensori, maka akan menyebabkan pasien DM berpeluang mengalami luka pada daerah kaki. Doctherman \& Bulechek (2004) menyatakan bahwa tindakan yang dapat dilakukan perawat antara lain manajemen sensasi perifer dan perawatan kaki.

Banyak penelitian yang membahas mengenai hal-hal terkait penanganan neuropati perifer diabetik, tetapi belum banyak penelitian terkait gambaran karakteristik penderita neuropati perifer diabetik. Penelitian ini bertujuan untuk mengetahui gambaran karakteristik penderita neuropati perifer diabetik.

\section{METODE}

Desain penelitian deskriptif analitik dengan teknik cross sectional. Sebanyak (35) pasien neuropati perifer diabetic yang menjadi sampel dipilih secara purposive sampling. Prosedur pengambilan data dilakukan selama 4 minggu di Ruang Poliklinik Penyakit Dalam RSUD Tugurejo Semarang. Instrumen yang digunakan untuk mengukur sensasi kaki yakni Siemens Weinstein Monofilament 10. Sedangkan kuesioner digunakan untuk mengukur karakteritik responden. Program komputer digunakan untuk mengolah data yang telah terkumpul. Adapun etika pengambilan data memegang prinsip self determinant privacy, anonimity, confidentiality confidentiality, dan justice. Analisis pada variabelvariabel di dalam penelitian ini dilakukan secara univariat.

\section{HASIL}

Terdapat 5 karakteristik responden yang akan ditampilkan, ke 5 karakteritik tersebut antaralain usia, jenis kelamin, lama menderita DM, terapi farmakologi, dan ABI. Rerata umur responden adalah 49.5 
(95\% Cl) dengan standar deviasi 6.7. Jenis kelamin dalam penelitian ini sebagian besar perempuan ( $\geq$ 68.4\%). Rerata lama menderita DM yaitu 4.6 tahun $(95 \% \mathrm{Cl})$ dengan standar deviasi 2 . Rerata nilai $\mathrm{ABI}$ adalah $0.85(95 \% \mathrm{Cl})$ dengan standar deviasi 0.05. Sebagian besar responden mengkonsumsi obat hipoglikemik oral $(\mathrm{OHO})$ sebesar $\geq 84.1 \%$. Skor rata-rata sensasi kaki panderita neuropati perifer diabetik $8 \pm 0,8$.

\section{PEMBAHASAN}

Rata-rata responden dalam penelitian ini termasuk kedalam klasifikasi lansia tengah dengan rentang umur 45 - 65 tahun. DM tiep 2 yang berumur kurang dari 70 tahun memiliki resiko lebih tinggi mengalami komplikasi mikrovaskuler seperti neuropati, retinopati, dan nefropati ( Floch, Doucet, Bauduceu, \& Verny., 2013). Adapun Hasil penelitian ini bertolak belakang dengan penelitian terkait lain, bahwa rata-rata usia penderita DM yang mengalami neuropati yakni berumur 55.1 tahun (Booya, et al. 2005). Hasil penelitian yang relevan lainnya menyatakan bahwa rata-rata umur penderita DM yang mengalami neuropati perifer diabetik adalah $44-58$ tahun ( Jember et al, 2017).

Jenis kelamin yang dominan pada penelitian ini adalah perempuan. Hal ini tidak sesuai dengan pendapat bahwa laki-laki beresiko 2 kali lebih besar mengalami luka kaki dibandingkan wanita. hal ini dikarenakan laki-laki lebih banyak merokok dan minum alkohol sehingga dapat merusak syaraf (National diabetes information clearinghouse, 2002). Penelitian relevan lainnya menyatakan bahwa perbedaan jenis kelamin dapat diartikan sebagai salah satu faktor yang berpengaruh terhadap kejadian neuropati, akan tetapi penjelasan ilmiah yang mendasarinya masih menjadi perdebatan dan diperlukan penelitian lebih lanjut (Katulanda et al, 2012). Menurut asumsi peneliti karena terbatasnya jumlah responden dan area penelitian yang hanya melibatkan satu rumah sakit, maka hal tersebut belum dapat menggambarkan proporsi mayoritas mengenai jenis kelamin yang mengalami neuropati perifer diabetik.

4.6 tahun lama rata - rata pasien menderita DM. Nilai tersebut sesuai dengan penelitian relevan lainnya yang menyatakan bahwa neuropati perifer diabetik yang dialami pasien DM terjadi sejak 3 5 tahun setelah terdiagnosa DM (Tefaye et al, 2005). Hasil penelitian yang relevan lainnya menyatakan bahwa lama waktu seseorang mengalami DM seiring dengan komplikasi yang akan ditimbulkan, artiya bahwa semakin lama mengalami DM maka semakin tinggi pula kejadian komplikasi yang dialami oleh pasien (Herrera-Rangel et al, 2014).

Hasil penelitian yang relevan menyatakan bahwa lamanya menderita DM dengan hiperglikemi mempengaruhi perubahan terhadap dinding pembuluh darah dan tekanan darah (Suzuki et al , 
2001). Kurun waktu 5-10 tahun seseorang terdiagnosis DM, akan menyebabkan terjadinya komplikasi lainnya. Teori yang relevan menyatakan bahwa penurunan fungsi sel beta pankreas seiring dengan lama seorang penderita DM terdiagnosis (Smeltzer \& Bare, 2010). Hal tersebut sesuai dengan teori yang menyatakan bahwa penurunan fungsi sel beta pankreas akan berdampak pada berkurangnya jumlah produksi insulin didalam darah akan menurunkan proses glikolisis didalam sel. Akibatnya glukosa yang tidak terserap oleh sel akan menyebabkan peningkatan akumulasi glukosa pada pembuluh darah dan menjadikan kondisi hiperglikemik (Corwin, 2009).

Hasil penelitian ini didapatkan hasil bahwa sebagian besar mengkonsumsi obat antihiperglikemik oral (OHO). Jenis $\mathrm{OHO}$ yang sering dikonsumsi responden adalah Metformin dalam jangka waktu minimal 1 tahun. Hasil penelitian yang relevan menyatakan bahwa bahwa pasien dengan neuropati perifer diabetik tipe II, dan mengkonsumsi metformin lebih dari 6 bulan memiliki serum rendah Vitamin B12 (Cobalamin/Cbl) dan tanda menunjukkan klinis neuropati perifer yang lebih parah dibandingkan dengan pasien yang tidak terpapar Metformin (Wile \& Toth, 2010). Pasien DM akan mengalami penurunan vitamin B12, rasa kesemutan pada tangan dan pada kaki serta mati rasa merupakan tanda dan gejala kurangnya vitamin B12 didalam tubuh (Gilligan, 2002).

Nilai $A B I$ pada penderita neuropati diabetik relatif tidak normal, hal ini sesuai dengan hasil penelitian ini yang menggambarkan perputaran aliran darah dalam tubuh berada pada tahapan gangguan ringan. Pernyataan yang relevan terkait hal ini adalah salah satu faktor penting yang akan menyebabkan masalah-masalah lainnya pada pasien DM seperti makrovaskular dan mikrovaskuler adalah gangguan pada pembuluh darah. Pada pasien DM, aliran darah akan terganggu dan menyebabkan terganggunya sirkulasi tubuh (Farmet, et al, 2005). Salah satu faktor yang berpengaruh terhadap nilai $\mathrm{ABI}$ adalah riwayat konsumsi merokok. Hasil penelitian lain juga bahwa riwayat atau merokok mempengaruhi pembuluh darah karena menyebabkan aterosklerosis dalam pembuluh darah. Akibat dari atersoklerosis tersebut akan meningkatkan tekanan sistolik yang akan berkontribusi besar terhadap nilai ABI (Jung, Chu, Bhan, 2011). Hasil penelitian lainnya yang relevan menunjukkan bahwa merokok merupakan bahwa merokok secara signifikan mampu meningkatkan resiko pasien DM mengalami neuropati perifer diabetik ( Clair et al, 2015).

Salah satu tanda penderita neuropati perifer diabetik adalah adanya mati rasa pada telapak kaki yang disebabkan gangguan sistem syaraf perifer yang sangat erat hubungannya dengan dampak hiperglikemik kronik dan faktor neurovaskuler. Akibatnya adalah pembuluh darah yang membawa oksigen dan nutrisi ke sel syaraf akan rusak (National diabetes information clearinghouse, 2002). Neuropati periper diabetik juga salah satu komplikasi akibat diabetes mellitu yang tidak kadar 
gulanya tidak terkontrol. Gula darah yang tidak terkontrol juga menjadi salah satu penyebab terjadinya luka pada kaki. Hasil penelitian yang relevan menyatakan bahwa peningkatan kadar glukosa pada darah dalam waktu yang lama akan menyebabkan terjadinya ulkus diabetik foot ( Dekker et al, 2016). Hasil penelitian lainnya menyatakan bahwa kontrol gula yang buruk juga akan menyebabkan munculnya gejala neuropati perifer diabetik (Zilliox et al, 2015).

\section{SIMPULAN}

Sebagian besar penderita mengalami penurunan sensasi kaki dengan lama menderita DM yang bervariatif. Umur penderita sudah memasuki dewasa akhir atau lansia awal dengan wanita yang paling banyak mengalami neuropati perifer diabetik. Terapi farmakologi $\mathrm{OHO}$ paling banyak dikonsumsi dan nilai $\mathrm{ABI}$ dalam tahapan yang mengalami gangguan ringan.

\section{SARAN}

Perlu adanya peningkatan pemahaman dan perilaku bagi para penderita DM untuk melakukan kontrol gula rutin, konsumsi obat, olah raga untuk mengurangi terjadinya kejadian neuropati perifer diabetik.

\section{DAFTAR PUSTAKA}

Booya, F., Bandarian, F., Larijani, B., Pajouhi, M., Nooraei, M, \& Lotfi, J. (2005). Potential risk factors for diabetic neuropathy : A case control study. BMC Neurol, 5, 24

Black, J.M., \& Hawks, J.H, (2009), Medical-surgical nursing: Clinical management for positive outcomes, Eight edition. Singapore: Saunders Elsevier.

Corwin, E. (2009). Hand book of pathophisiolofy. Philadelphia : Mosby

Clair, C., Cohen, M.J., Eichler, F., Selby,K.J., and Rigotti, N.A. (2015). The Effect of Cigarette Smoking on Diabetic Peripheral Neuropathy: A Systematic Review and Meta-Analysis. J Gen Intern Med. 30(8):1193-203. doi: 10.1007/s11606-015-3354-y. Epub 2015 May 7

Dochterman, J.M, \& Bulechek,G.M.(2004). Nursing intervention classification (NIC).(4th ed). St.Louis: Mosby.

Dekker, R.G., Qin, C., Ho, B.S., and Kadakia ,A.R. (2016). The effect of cumulative glycemic burden on the incidence of diabetic foot disease. J Orthop Surg Res. 18;11(1):143.

Farmet, E.(2005). Diabetic foot ulcer. The journal of american medical association, 293. http://Jama.ama-assn.org/cgi/content/full/293/2:135 
Floch, J.P., Doucet, J., Bauduceau, B., \& Verny, C. (2013). Short report: Complications retinopathy, nephropathy, periperal neuropahty and geriatric scale scores in elderly people with type 2 diabetes. Diabetic Medicine, 31, 107-111

Gilligan, M.A. (2002). Metformin and vitamin B12 deficiency. Arch Intern Med, 162, 484 485Ignatavicius, D.D., \& Workman, M.L. (2006). Medical surgical nursing: Critical thinking for collaborative care. Fifth edition. St. Louis, Missouri: Elsevier Saunders.

Herrera-Rangel, A., Aranda-Moreno, C., Mantilla-Ochoa, T., Zainos-Saucedo, L., \& Jáuregui-Renaud, K. (2014). The Influence of Peripheral Neuropathy, Gender, and Obesity on the Postural Stability of Patients with Type 2 Diabetes Mellitus. Journal of Diabetes Research, 2014, 1-7. doi:10.1155/2014/787202

Jung, K., Chu, K., Lee, S., Bahn,J et al. (2011). Risk of macrovascular complications in type 2 diabetes mellitus: Endothelial microparticle profiles. Cerebrovascular diseases, 31(5), 485-493

Jember, G., Melsew,Y.A., Fisseha, B., Sany, K., Gelaw A,Y., and Janakiraman, B. (2017). Peripheral Sensory Neuropathy and associated factors among adult diabetes mellitus patients in Bahr Dar, Ethiopia. J Diabetes Metab Disord.16:16. doi: 10.1186/s40200-017-0295-5

Katulanda, P.,Priyanga,R.,Ranil,J.,Gidwin,R.C.,Rezvi,S.,David,R.M.(2012). The prevalance, patterns and predictors of diabetic peripheral neuropathy in a developing country. Diabetology \& Metabolic Syndrome,4, 21-29

Kohnle (2008). Symptom of diabetic neuropathy, http://diabetes.niddk.nih.gov/dm/pubs/neuropathies

LeMone, P, \& Burke .(2008). Medical surgical nursing : Critical thinking in client care.( 4th ed). Pearson Prentice Hall: New Jersey.

National Diabetes Information Clearinghouse. (2005). Total prevalence of diabetes in the Unites States. http://diabetes.niddk.nih.gov/dm/pubs.htm

Suzuki, E., Kashigawi, A., Nishio, Y., Egawa, K., Shimizu, S., \& Maegawa, H. (2001). Increased arterial wall stiffness limits flow volume in the lower extremities in type 2 diabetics patients. Diabetic care, 24(12), 2107-2114

Smeltzer, S.C., Bare, B.G., Hinkle, J.L., \& Cheever, K.H. (2008). Brunner \& Suddarth's textbook of medical surgical nursing (11th ed.). Philadelphia : Lippincott Williams \& Wilkins.

Wile, Daryl. J., and Toth, Cory. (2010). Association of Metformin, Elevated Homocysteine, and Methylmalonic Acid Levels and Clinically Worsened Diabetic Peripheral Neuropathy. Diabetes Care. 2010 Jan; 33(1): 156-161

Tesfaye, S. (2006). Diabetic neuropathy. In; Veves A, Giurini JM, LoGerfo FW, editor. The Diabetic Foot, Second Edition. New Jersey: Humaniora Press

Zilliox, L.A., Ruby, S.K., Singh, S., Zhan, M., \& Russel, J.W. (2015). Clinical neuropathy scales in neuropathy associated with impaired glucose tolerance. Journal of diabetes and its complications, 29, 372-377 